\title{
懇話会の出発の頃
}

岡山大学教育学部

伊澤 秀而

\section{The Dawn of JSPP: Debates Began at the Late 1960s}

\author{
Shuji Izawa \\ Faculty of Education, Okayama University \\ 3-1-1 Tsushima, Okayama, Okayama 700-0082, Japan
}

昭和 43 年（1968 年）に遡る。 5 月だつたと思うが, 東京教育大の岩原信九郎先生から“生理心理学の討論 会を企画した。学会などではあまり具体的な討論もで きないので，自由に意見交換をする気楽な集まりを持 ちたい。”というご案内をいただいた。このお誘いで, 翌 6 月の初旬 8 日, 夕刻 2 時間の予定で 30 名ほどが 当時の東京教育大（現在は筑波大東京キャンパス）の 会議室に集まつた。永村寧一氏から脳波の多変量解析 をテーマにネコの前頭部脳波のパタン解析のデータ提 供があって，遠慮のない意見の交換があったのを憶え ている。

この討論会の火は引き継がれて, 続いて翌 7 月, 新 見良純先生の企画で早大で 2 回目が開催された。生理 心理学・精神生理学懇話会と名乗つて開催され, 略し て懇話会という名がこの会の通称になったのはこの時 からである。皮膚電気活動をめぐっての討論のほか, わが国の精神生理学研究の動向を海外に紹介する企画 についての協議など, 成果を収めて, 次回は秋にと予 定して終わつた。

だが折り悪しく, 1968 年から 1970 年は大学紛争で
大学が苦悩に満ちた時代であった。大学の閉鎖や混乱 で懇話会の開催も次第に難しくなり，隔月には開きた いと考えていた会だつたが，しばらくは見送るほかな いという事態になってしまった。結局, 次の懇話会を 開くことができたのは翌年の春であった。

筆者は当時, 東京学芸大にいた。特殊教育の大学附 属研究所（東京学芸大学特殊教育研究施設）ができて すぐの頃で, ここで心身障害の研究に携わつていた。 特殊教育は, 今の学校教育法では特別支援教育と改称 されているが, 生体系から切り达む課題の多い教育領 域である。それだけに懇話会との縁も深かった。

中断後の第 3 回懇話会の再開は, 大学でも研究所の せいで平穏だった私どものところで担うことになっ た。久し振りの開催であった。保存してある開催案内 を見ると, 中断, 再開の経過が記してあって感慨が深 い。その文面を抜粋して載せておきたい。

“昨年 7 月の第 2 回懇話会（於 早稲田大学）にお 集まりいただいたまま, 以後の開催が遅れご迷惑を おかけしました。ご承知の通り, 第 3 回懇話会は, 日本大学の山岡 淳先生のお世話で昨年秋に開催と

2012.8.28 受稿，2012.8.28 受理，2012.12.28 J-STAGE 早期公開， doi: 10.5674/jjppp.1207si, JOI: JST.JSTAGE/jjppp/1207si 連絡者及び連絡先 : ₹ 700-0082 岡山市津島 3-1-1 岡山大学教育学部 伊澤秀而 Tel: 086-272-7455 
いうことに決定しておりましたが, 周知の日本大学 のご事情で開催の見通しが立たない状況にありまし たので, ご依頼により東京学芸大学でお引き受けす ることに変更いたしました。しかしその後も, 東京 大学, 東京教育大学ほかの学内事情も重なり, 開催 日時を決めかねておりましたため, 結局今日までに 至った次第です。”

第 3 回の懇話会は 1969 年 4 月 12 日, 地下鉄虎ノ門 駅に近い国立教育会館の会議室を借りて行われた。大 学が都心から離れていて, 往来の便を考えてここを借 りたが，そのお陰で，その時に提出した施設利用申込 書が書類として残つている。これには, 参加予定人員 $40-50$ 名, 使用時間 $14-19$ 時, 使用料 4,800 円と 記してあって, 国立教育会館の承認印が押してある。 当日の出席者数は, 見込んだ通りだったと思う。使用 料は, 今 1,000 円が普通の科学雑誌が 200 円であった 時代の 4,800 円である。捻出に心配したが, 大学の経 費で賄うことができた。国立教育会館は, 法の廃止で, その後 2001 年に解散して現在はない。改めて, 時の 流れを感じている。

東京学芸大附属の特殊教育研究施設には, 生理心理 学関連分野を扱つている部門が二つあつた。当日の話 題もそれぞれ一題ずつ出すことにして, 第一部門の水 谷徹氏と第三部門の筆者が担当した。水谷氏からは閃 光誘発電位と覚醒水準をテーマに話があり, 筆者は, 脳波のパタン解析とその方法論について研究の現状を 披露することにした。

誘発電位は, 中枢応答過程を取り出している点で, 認知情報処理の神経過程をほどく糸口になる。しかし， いわゆる誘発加算法によって自発背景脳波から平均電 位を分離する電子工学技術は, 当時, ようやく緒につ いたばかりであった。こういう状況にあって, 先駆的 な実験の実情を話してもらえたのは何よりだつた。

脳波のパタン解析については, Gibbs のアトラスを 材料に, 生後 7 週から 37 歳までの 8 誘導脳波を計算 機で分析して, 脳波パタンの多変量定量化と発達情報 の検出を図った追跡の成果を紹介した。1966 年の脳 波学会に出したものだが，まだ実験室に計算機がな $く$, 共同利用機関であった東大計算機センターに足繁 く通ってオフラインで処理していた時期である。当然, 未開拓の領域であった。

懇話会が終了したあと, この日は同じ会場で, 予
め案内してあった 3 年後の国際心理会議（第 20 回 1972 年東京で開催）についての懇談も行われた。会 場を 7 時まで借りておいた(前述)のはこのためであっ た。同国際会議のシンポジウム（生理部門）の企画に ついて, 組織委員会から懇話会に検討の依頼があった からである。

発足 2 年目のこの年は, 懇話会はこのあと 6 月に第 4 回, 9 月に第 5 回と継続して開催された。第 4 回は 日大の山岡先生のご担当で虎ノ門共済会館であり, 第 5 回は東大医学部の平井富雄先生の企画で赤門学士会 館にて行われた。前に触れたように, 山岡先生には第 3 回㴧話会を主催していただくはずであった。事情止 むなく筆者が交代したが, 時が至り, 当初の計画通り 日大主催で実現したのが第 4 回の懇話会であった。第 4 回は 2 題, 第 5 回は 3 題の話題提供があって討論が 行なわれている。

こうして懇話会は 3 年目を迎えた。1970 年である。 第 6 回は春, 第 7 回は年の瀬に開催された。出発の時 に戻って, この 2 回はそれぞれ, 東京教育大, 早稲田 大の主催で行なわれた。懇話会が序章を終えて, いよ いよ本論に入るのかという思いであった。この年，筆 者は渡米, 次の年の秋まで留守にしていたので, どち らの会議にも出席できなかった。

草創期の懇話会の姿は, 見てきたように, 近隣の研 究同人が集まって話す勉強会であった。人数も多くて 50 人, 土曜日の午後数時間の懇談が慣例で, 紛れも なく懇話会だつた。まだ会の正式名称もなく, 生理心 理学・精神生理学懇話会と呼んだり, ある時は生理心 理学懇話会であったりもした。心理学と生理学の境界 領域をどう呼ぶのが正当か, 本格的な議論は残してま ず出発したのであった。

その頃, 今は廃刊になっているが科学雑誌 “自然” の 1968 年 8 月号に, 物理学の早川幸男氏の “ロビー での科学”之題した随想が載つた。科学の専門分野で の情報交換のことに触れたものだが, 談話の効用のこ とが書かれていた。

“学術会議では講演のセッションそのものよりも, 休蒩の時に一対一で行われる談話のほうが味が深い。 それは堂々たる講演の裏にあるごたごたした台所の様 子や，秘密情報であったりもする。これはもう情報の 交換というより人間と人間のふれあいと言つたほうが よいのかも知れない。学問は高度になればなるほど個 
性が強く入ってくるから，ロビーでする一対一の話し 合いが大切で，これこそ学術的会合の最大の効果であ る。”(要旨)

氏の執筆は，その少し前に東京で開かれた国際宇宙 空間研究会議を振り返つたものであった。会議の本舞 台とは別に，休䡯時間にロビーで交わされた対話に実 は測り知れない価値があった。こういう論旨である。

われわれの懇話会が創始された時の精神も同じで あった。本稿の冒頭で, 岩原先生から最初に届いた発 会の案内のことを紹介したが，その文面を見てもこの
ことが歴然としている。

学際領域，境界領域など，新しい学問領域の開拓へ の挑戦が盛んになってきたのは 1950 年代からだった ろうか。たとえば, 生物物理学の領域が本格化し始め たのもこの年代の後半である。それでも，その必要 性が叫ばれてから 10 年以上を経ていると聞いていた。 懇話会が生まれて，これから 10 年かかるのか 20 年か 分からないが，われわれも，いよいよ新しい境界領域 を築く原点に立つたと感じたものだつた。 